Article

\title{
Straddling the Fence: Land Use Patterns in and around Ports as Hidden Designers
}

\author{
Lucija Ažman Momirski ${ }^{1}$, Yvonne van Mil ${ }^{2, *}$ and Carola Hein ${ }^{2}$ \\ ${ }^{1}$ Faculty of Architecture, University of Ljubljana, Slovenia; E-Mail: lucija.azman@fa.uni-lj.si \\ ${ }^{2}$ Faculty of Architecture and the Built Environment, Delft University of Technology, The Netherlands; \\ E-Mails: y.b.c.vanmil@tudelft.nl (Y.v.M.),c.m.hein@tudelft.nl (C.H.) \\ * Corresponding author
}

Submitted: 30 January 2021 | Accepted: 12 May 2021 | Published: 27 July 2021

\begin{abstract}
Ports are clearly demarcated structures on land and water. They are fenced in, easily recognizable on satellite and orthophoto images, and they have specific functions. This apparent clarity of ports, their function and outline, in relation to nearby urban and rural areas, becomes more complex when explored through the lens of land use, that is the existing and planned future functional dimension or socio-economic purpose of the land. In contrast to urban and rural areas, where land use has been mapped and defined for centuries, the use and function of land and water in port areas has long been multifunctional and not defined on land use maps. This raises questions about the role and understanding of port territory in relation to neighboring spaces, past, and present. This article first defines land use and describes its historical development. Scholars from various disciplines, including geographers, planners, and economists, have addressed the issue of land use in port areas. Land use patterns have emerged over time and are based on earlier demarcations of port areas and distinctions between port and city. As shown by the historical port city borders in Hamburg, Rotterdam, and Koper, these delimitations can change over time, by location and by function. The land use register has only recently been harmonized at the European level. European and national registers distinguish existing and planned land use in port areas differently. Mixed uses prevail in new port interventions, creating a new kind of permeability or porosity; that is, areas where port, urban and rural functions merge. New land use porosity is a particular state of land use (on both sides of the boundaries of port areas) that goes beyond the physical boundaries marked by fences. Land use porosity effectively creates land use continuity, a functional porosity that serves as a hidden blueprint for future planning. Understanding land use porosity can provide a foundation for novel approaches to the development of transition strategies that are needed to address contemporary challenges, including climate change and sea level rise, digitization, and new work and life practices in port city regions. In conclusion, we note that due to the porosity of land use patterns, the separation between the present port and the city is beginning to crumble. However, this process has yet to be made fully visible and used as a basis for design.
\end{abstract}

\section{Keywords}

boundaries; Hamburg; Koper; land use; planning; porosity; port city; Rotterdam

\section{Issue}

This article is part of the issue "Planning for Porosity: Exploring Port City Development through the Lens of Boundaries and Flows" edited by Carola Hein (Delft University of Technology, The Netherlands).

(C) 2021 by the authors; licensee Cogitatio (Lisbon, Portugal). This article is licensed under a Creative Commons Attribution 4.0 International License (CC BY).

\section{Introduction}

Port areas are clearly recognizable structures on satellite and orthophoto images of metropolitan areas, similar to airports, traffic systems, and industrial areas.
Usually, port areas are surrounded by physical fences, such as walls, wire fences, metal fences, boards, and large infrastructures, that separate the port territory from other urban and rural landscapes. Within the port areas, some functions can be visually identified: water 
basins, including berths, storage areas, and industrial production or administrative sites. However, many invisible boundary lines-such as land use borders-remain unseen in situ and in aerial observation and exist only in specific inventories. Although largely invisible, these land use designations can have long-lasting impact on a port's spatial development and on the urban and rural areas in its vicinity. Many ports are industrial hubs, and designation as an industrial site-for example for an oil refinery-will affect neighboring areas-their livability, functional assignment, or land price-because of air, water, or sound pollution (Hein, 2018a, 2018b). Polluted soils will affect the use of the site for decades to come, although this information is not included in land use databases. The land use designations in the port, however, are different from those used in urban and rural areas. In fact, port territories are not as mapped and defined in terms of land, water, use and function; changes in function are not updated, and at times the area is left completely empty in land inventories.

Since containerization in the 1960s, the explosive growth of port areas has led to remarkable changes in land use. Due to the expansion and functional upgrading of these areas that are located at the edge of sea and land and in the vicinity of large city regions, the land use patterns and resulting changes have become even more significant. To achieve an integrated planning that respects the environment and the health of nearby communities, contemporary planning for urban and regional areas is moving away from traditional technocratic statutory planning, that is, away from regulating land use plans, and toward a more collaborative and actor-based approach (Albrechts, 2006). In some cases, port authorities try to adapt their own land use plan to the surrounding areas and support participatory planning approaches to guarantee the sustainability of port city land use. An integrated approach to the multifunctional planning of ports is necessary (Ažman Momirski, 2017).

Planning practices are changing (in port areas as well as outside them), but one of the most important foundations for urban planning still remains land use data, including land use by type (residential, commercial, industrial, recreational, open space, institutional, etc.; Kliment et al., 2014). However, a lack of detailed types of land use undermines planning in and at the borders of ports. The blankness (Kipnis \& Maymind, 2013; Unger, 1991) when it comes to land use within port areas poses a challenge for future planning, especially regarding environmental impact, energy transition, and contact with neighboring urban and rural areas. It also raises questions regarding the role and understanding of the port territory. What is needed is a more comprehensive approach to land use, treated as a process by which humans transform land. Subsequently, the process of land use should be studied as a system and important feedback, interrelations, interconnections, and interdependencies should be taken into account (Kostrowicki, 1983):
At the level of policy, categorisation of areas, uses and covers plays an equally important role. The categorisation of an area as either nature reserve or industrial will have a clear impact on future economic decisions. Thus, the relation between categorisation and decision-making may be invisible but is evidently powerful. (Jansen et al., 2014, p. 320)

To better understand the challenges created by the interrelated development of two areas, one controlled by national, regional, or local urban land use planning and the other usually exclusively in the hand of port authorities, we explore the interconnectedness of land use on both sides of the fences surrounding ports. We stipulate that there is a certain continuity in land use, which we call land use porosity. This permeability of land use on both sides of the fence in some ways mirrors the permeability of functions from land to water (and vice versa), which has led to the construction of docks and other spatially defined objects in the past (i.e., parallel to the perpendicular movement of flows in relation to the coast as well as inland), and these functions still exist today. Land use porosity emerges at the landward border of the port. It is caused by the overflow of land uses from and around the current port's fringe area, even if no gates exist in the fence. The continuity comes about through invisible influences, such as pollution (not shown in land use keys as represented in plan legends) or green systems entering the port area (defined in the land use categories). Pollution effectively expands port (industrial) areas, and green systems seemingly shrink them.

Although the port is surrounded by fences, some land uses appear in both port and urban or rural territories that are close to each other. This process effectively dissolves borders as it creates continuous land use patterns between the surrounding areas and the port and it expands land use porosity by pitting highly defined land uses in urban and rural areas against much less specific land uses in the port. Moretti (2019) similarly observed that the areas dedicated to port activities can be considered functional sectors that are constitutive parts of a developing organism. Land use patterns in and around port areas effectively become a hidden designer of port uses in space. As port fences become invisible, the longevity of these patterns is inscribed in the urban and rural landscapes, but not in those of the port, effectively providing the port with planning powers beyond its boundaries.

Adding to the complexity of the phenomenon of expanding port territories, such situations occur in different topographical settings (e.g., bays, islands, open coasts, inlets), within different morphological structures (e.g., linear, circular), in ports of different functions (e.g., industrial, commercial, traffic), operations (e.g., loading, unloading, transshipment of cargo to and from the vessels, storage), sizes (e.g., very small, small, medium, large, and very large-based on tons of cargo handled during the year, hinterland size, and importance) and 
governance models (e.g., public, private, or mixed management entities). While size may influence the form of land use porosity (e.g., monofunctional areas v. mixed uses), the port typologies are not reflected in land use categories and the governance models do not define land use categories in the port areas (e.g., public-private management does not have an influence on land use categorizations, as the land use register is predefined). Port authorities need to adapt their functions, operations, and activities to critical issues at port boundaries (environmental issues, etc.) and negotiate with state, municipal, and other authorities concerning the impact of the border land use (e.g., on water quality, air quality, noise, carbon footprint, marine ecosystems, terrestrial habitats). To better understand the role of port borders in space and through time, this article first explores land use in port areas through time, land use classification in existing land use data sets, and their national and international alignment. We conclude by considering whether port land use categories require defined types of land use data sets, and whether the land use nomenclature should be adjusted according to the differences of ports in size and function (e.g., small or large transit ports), different social systems (e.g., Western, Central, Eastern, Southern European ports) and different parts of a continent or sea (e.g., North Sea ports, Ligurian Sea ports, Adriatic Sea ports). In order to find an answer to these questions, this article examines the characteristics of land use, internal and external port boundaries over time and today in three port cities-Hamburg (Germany), Rotterdam (the Netherlands), and Koper (Slovenia)-selected here as pilot studies because of the authors' advanced knowledge of these three sites.

\subsection{On Land Use}

Urban and rural territories are defined by land use, which is, according to an INSPIRE directive, a "territory characterised according to its current and future planned functional dimension or socio-economic purpose (e.g., residential, industrial, commercial, agricultural, forestry, recreational)" (European Parliament \& Council of the EU, 2007, p. 13). This description is not limited to land areas, but also includes the sea. INSPIRE states: "The inland water bodies as well as coastal waters are considered within the connected piece of land and planning of the use of sea and the use of seabed has been taken into consideration" (INSPIRE Thematic Working Group Land Use, 2013, p. VI). Land use is registered in a database on a national or supranational level, which separates the existing land use ("the use and functions of a territory as it has been and effectively still is in real life" [INSPIRE Thematic Working Group Land Use, 2013, p. VI]) and the planned land use ("which corresponds to spatial plans, defined by spatial planning authorities, depicting the possible utilization of the land in the future" [INSPIRE Thematic Working Group Land Use, 2013, p. VI]).
Land use does not match the existing land cover, that is, the "physical and biological cover of the earth's surface including artificial surfaces, agricultural areas, forests, (semi-)natural areas, wetlands, water bodies" (European Parliament \& Council of the EU, 2007, p. 229). With new technologies for surveying land using satellite imagery and with the ability to abstract the earth's surface, land cover, as an abstraction of the surface, has emerged as another mapping category alongside land use. Land cover is mapped and recorded through land cover survey initiatives (EEA CORINE land cover program [Copernicus, 2016]; Urban Atlas by the European Environment Agency [Copernicus, 2018a]; LUCAS survey by Eurostat [Eurostat, 2021]). Land cover data are used to monitor changes in land cover and climate variables and are an analytical tool. Land use cannot be determined using (only) land monitoring techniques and requires direct field observation. Land use is thus both a record of existing functions and a future-oriented planning tool.

\subsection{Historic Development of Land Use}

Using land use as a planning tool requires careful documentation of existing patterns. Cadastral maps (a longstanding tool around the world) and land registration have evolved over centuries to track land use (the notion of the cadastre has been associated with the Byzantine books, called katastichon in Greek, which literally means 'line by line' [Stubkjær, 2008]). Cadastral maps document the partition of territory in parcels; they are linked to ownership and serve as an official land register. The cadastre connects rights in rem-that is, to an object-but in this case to real estate (plots of land listed in the land register) with a location in space; that is, the cadastre locates a property in space, or it connects space with the owner. In the land cadastre, written and graphic data are kept for each parcel. The first, written part of a cadastre defines data such as parcel number, boundary, area, owner, administrator of state or municipal property, actual use, built-up area, and credit rating of the land plot. The graphical display of the land plots is the cadastral representation, which shows the boundaries of parcels, parts of parcels and parcel numbers (Kadaster, 2021; Working Committee of the Surveying Authorities of the Laender of the Federal Republic of Germany, 2020; The Surveying and Mapping Authority of the Republic of Slovenia, 2020). A cadastre provides legal certainty (Kadaster, 2021).

Since antiquity, one of the main aims of the cadastre was to support land taxation policies (Richeson, 1966). Dobner (Dobner, 1973; National Research Council, 1980, p. 6) has argued that almost all European cadastres were established in response to the need for fiscal information. Most properties in medieval and early modern Europe were managed without the aid of maps. Throughout the 15th and 16th century, large-scale maps came to supplement medieval written cadastres as inventories of property. Over centuries the property value of the 
land in general, and around port areas in many parts of Europe, increased. Consequently, the manner and style of property mapping became more precise. In Central Europe, the Milan cadastral mapping program, carried out between 1720 and 1723, was the only fully surveyed and mapped cadastre with graphical presentation for more than a century (Kain \& Baigent, 1992). The Franciscean or Stable cadastre, from the first half of the 19th century, notably contains, in addition to written records, cadastral maps at a scale of $1: 2,880$, showing land use (Bičík et al., 2015).

Agricultural cadastral cartography was the basis for the development of new land uses for urban, industrial, and other types of development, and was (most importantly) used to delineate private property and ecclesiastical and aristocratic estates. Land ownership maps were critical for securing rights to real property (whether residential or productive, such as mills and workshops) and land resources (arable land, fields, forests, and pastures). In the 17th century, Europeans developed an understanding and appreciation of the cadastral concept for purposes beyond taxation in the development of the legal or judicial cadastre. Starting at the end of the 18th century, cadastral maps were increasingly related to or based on geodetic triangulations (e.g., the case for the Napoleonic cadastre of France, Belgium, the Netherlands, and the Napoleon-occupied areas in Germany, left of the river Rhine; Kain \& Baigent, 1992).

These detailed maps served land ownership and taxation purposes. Port lands were long owned by the state/crown, so goods were taxed rather than land. Consequently, port areas were historically not defined by land use and by the land registry. However, there were other demarcations and separations, but also inclusions between the city and the port, such as physical barriers and functional designations (which we do not treat as land use given the definition provided in Section 1.1).

\subsection{Previous Research on Land Use in and Around Port Areas}

Land use in port areas differs from that in cities and rural areas. Scholars from various disciplines have addressed this topic. Canadian geographer Charles Nelson Forward $(1968,1969,1970)$ has written about land use in waterfronts in the context of metropolitan areas and compared the waterfront land use structure of different port cities. Forward (1969) argues that although each port city is unique in terms of location, setting, and physical characteristics, one would expect similarities in waterfront land use patterns in cities with reasonably uniform culture and economic development, and this is currently not the case. In 1983, the United Nations published the report "Planning Land Use in Port Areas: Getting the Most out of Port Infrastructure" (Takel, 1983), introducing land use categories in port areas with the aim of unifying land use data sets for the EU as well as on a global level.
Selected authors have recognized the complexities of port transformation and the difficulties that issues of land ownership and control can create, especially in a time of transformation. Economist Reginald Loyen from KU Leuven (with Erik Buyst and Greta Devos; Loyen et al., 2003) summarized, in terms of land use and land use policy, the changes that took place in Rotterdam and Antwerp as they developed into modern ports, showing that quay and land use policy in the ports has long been a delicate issue. The port of Antwerp has evolved from a traditional transshipment port to a multifunctional port. The classic cargo-handling function has been complemented by a wide range of logistics services (warehousing, distribution, value-added logistics, semiindustrial activities, etc.) as well as port-related industries. Rotterdam managed to make land available for commercial functions through the construction of new ports prior to 1940 and later. In 1960-65, companies that carried out large cargo transports were given preference in renting port land. In this way, companies that transported, handled, or processed large quantities of goods found their way to the port, and the city made extensive land available to them. The availability of land and flexibility regarding new land uses was a key factor in the growth and transformation of Rotterdam into a world port.

Economist and port and logistics adviser Peter De Langen (2005) emphasizes that mixed land use in ports is a strength in a port's functional organization and at the same time an increasingly attractive basis for port planning. The Canadian planner Peter V. Hall and the German geographer Markus Hesse (2013) addressed the relationship between systems of physical flows and cities, which seem to be increasingly separated from each other (an example of the tensions between the two is the regionalization of ports and the expansion of port-related activities and facilities away from the historic waterfront), even though the management of flows requires spatial capacities and associated land use. In the same compendium, Heike Flämig (2013) argues that transport and land use planning measures are only successful in combination with environmental standards, also when influencing the locations of inland port areas. Canadian planner Clarence Woudsma (2013) stresses that logistics activities and associated flows-which are often linked to ports - have not been well integrated into the urban planning process, despite urban planning's emphasis on intensification, mixed land use developments, and active transport for quality of life and health in the cities. There is no coordinated approach to land use and the principles of 'restrict and regulate' rather than 'understand and adapt' have been applied to logistics land use activities, which is true even in logisticsoriented communities such as large ports, and manifests itself in pressure for port land to be developed as residential and recreational areas rather than for industry or logistics (Hall, 2007). 


\section{Delimitation of the Port Areas}

Port areas are located at the boundary of water and land. On the land side, they control flows of goods and people from port to city and hinterland, and, on the seaside, they control the connection between land and sea. Port areas and "waterfronts are typically places where the movement or flow of people, nature, goods and capital make their entrances to and exits from the city, and where they leave their marks on it" (Desfor \& Laidley, 2011 , p. 3). Therefore, delimitations in and around port areas have been caused by restrictions and by the implementation of controls over the territory and over the movement of goods and people.

The main reason for delimiting a port territory has always been the desire to control and govern the space in line with maritime interests. In the article "Early Medieval Port Customs, Tolls and Controls on Foreign Trade," Middelton (2005) points out that coasts and river systems in Europe have been divided into toll or customs areas since Roman imperial times, as well as in the Middle Ages and up to the present day. In the medieval urban tradition, towns whose main activity was trade, and which were located either on the banks of a major river or on the sea, were appointed ports (Antunes, 2010). In England, ships were allowed to load and unload only in ports so assigned and designated, at least since the 12th century. This procedure, however, necessarily required that the ports that received this "civil signature" were not only properly designated and appointed as such, but also properly delimited and defined. Even the earliest surviving texts (see Boys, 1792, p. 549) attest to the necessity to delineate assigned ports not only in terms of length along the coast, but also in terms of depth inland (Jarvis, 1959). The word 'port' was used not only to refer to a place, but also in a more precise sense, as a technical term denoting a specific, delineated length of coastline based on a privileged harbor-a fiscal 'collection' (Jarvis, 1959). There were ports that were privileged for foreign trade, and on the other hand, there were places that were restricted to coastal traffic (Jarvis, 1959). The definition of boundaries was important in combating smugglers. The question of a port's seaward boundaries was often a very practical matter of knowing whether a particular smuggler was inside or outside the boundaries of a port for purposes of inspection, forfeiture, and legal proceedings. One purpose of establishing boundaries was to prevent the passage of smugglers.

The definition of a port city is not insensitive to time and the evolution of the relationship that links the two parts and the two territories. In the 20th and 21st century, the dynamics and uncertainty of the commercial world, combined with the impact of the global economy, have profoundly changed the relationship between city and port, causing an irreversible rupture in the evolution of the two poles. Numerous authors from many disciplines have reflected on and theorized the relationship of port and city through the centuries, also pro- viding insights on scales and methods of investigation (e.g., Hein, 2011; Hein \& van Mil, 2019; Hoyle, 1989; Lee et al., 2008; Lee \& Ducruet, 2009; Schubert, 2011; Van den Berghe, 2016). Close spatial and functional association between the port and the city in most cases until the 19th century enabled the porosity between them. Expanding port areas beyond the city areas and/or perimeter walls diminished the previous permeability of functions. This can be well represented by the case of the port of Trieste, where authorities separated the city and the port by a fence in the late 19th century. In 1891, the free city port status was valid only for the area of the Porto Vecchio and the eastern dock, Punto Franco Nuovo ("New Free Port") or Franz Joseph Hafen (Minca, 1995). In a free port area, goods in transit were exempt from customs duties and commercial and industrial activities remained untaxed to support the upgrading of the port. New regulations formalized the physical and functional separation of the city from the port (Minca, 1995), disrupting the intensive functioning of the port system and requiring many new investments. As can be seen in various maps of Trieste from 1900 on, the port area is already drawn blank (with no definition of land uses) at that time, and in some versions only warehouses are identified along the operational coast and on the piers.

In the 20th century, commercial and industrial growth led to the progressive separation of port cities, as ports became more specialized (e.g., container ports, liquid bulk ports, passenger ports), industrialized (e.g., port-led industrialization through locating manufacturing centers closer to the ports or within the port areas, coastal economic zones), protected (e.g., safety measures, physical security barriers), and controlled (e.g., regulating and monitoring the access, arrival, stay and departure of ships), all with the aim of increasing efficiency. Physical delimitations were clearly defined by fences and controlled entrances and land use supported this division, especially at borders separating the port area from the neighboring city and rural spaces.

\subsection{Historical Port City Borders in Hamburg, Rotterdam, and Koper}

The study of individual port cities can shed light on the process of delineations and permeabilities of space in and around port spaces. The topographical settings and the historical circumstances which influenced the development of the selected three port cities are quite different. The relation between the city and the port also differed. In Hamburg, port and urban spaces were multifunctional for many centuries. In Rotterdam, port and city were first physically separated by a dike (a barrier which regulates or retains water from a river, lake, or even the sea) and by functions (Hein \& Van de Laar, 2020; Meyer, 1999), and only later in the course of the 17th century, the separation of functions between the port and the city blurred, with the areas becoming both multifunctional and representative. A defensive wall separated 
the town and the harbors in Koper, which was originally located on an island (Figure 3a).

Both Hamburg and Rotterdam were surrounded by strong walls and canals (Figure 1 and Figure 2a), and they developed a dense spatial pattern, with agricultural land uses outside the city walls (Figure $1 \mathrm{a}$ and Figure $2 \mathrm{~b}$ ). The port of Hamburg was located within the city walls on the Elbe River and grew along with the city. The flow of ships up and down the Elbe was constant, with two larger water basins for waiting ships to enter the port within the city (Figure 1a), which enabled the city to control the permeability of ships with cargo. Warehousing, living, and administrating all occurred in the same buildings, and small ships entered the canals that ran through the city. There was neither a clear distinction between dedicated port areas with fixed infrastructures nor a specific labeling of multifunctional spaces. In Rotterdam, the situation was different, as the oldest part of Rotterdam grew behind the dike, but to the south and outside the dike the port was built, and it introduced the distinction between the Landstadt (Polderstad) and the new Waterstad (the new part of the city). Originally, the former represented the city, and the latter the port with harbors, quays, warehouses, and shipyards (Meyer, 1999): "The relationship between the city and port was organized on the scale of individual land parcel, with an imposing front side for the home or office, and a rear side for the warehouse or other port-related activity" (Meyer, 1999, p. 293). In contrast to Hamburg and Rotterdam, Koper did not experience multifunctional spaces during the period when it held a monopoly as a salt port in the eastern part of the northern Adriatic (since 1182).

In the 19th century, with industrialization and the arrival of new forms of transport, private actors, and port companies, some municipalities in Hamburg and Rotterdam created their own port areas separate from
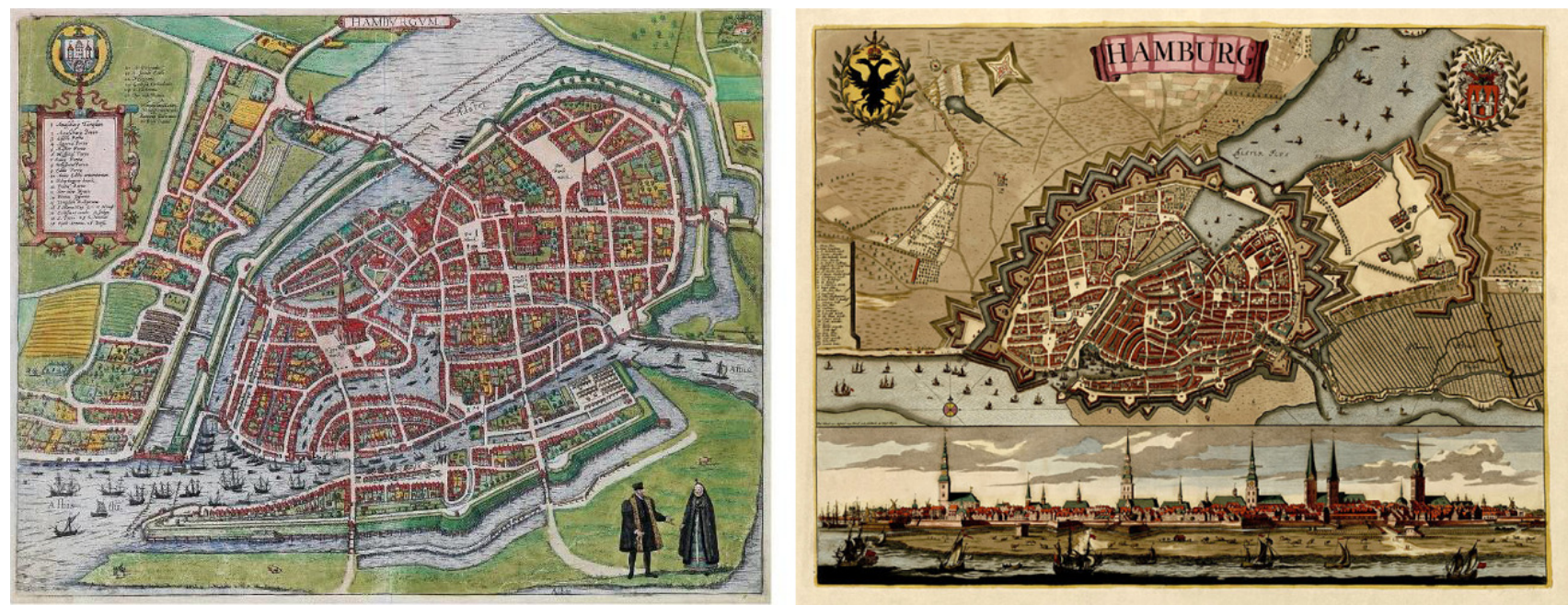

Figure 1. Hamburg in 1589 and 1690. (a) Hamburg in 1589, kol. Kupferstich von G. Hufnagel (left); (b) Hamburg in 1690, kol. Kupferstich von P. Schenk (right). Source: Hoffmann and Frank (2009).
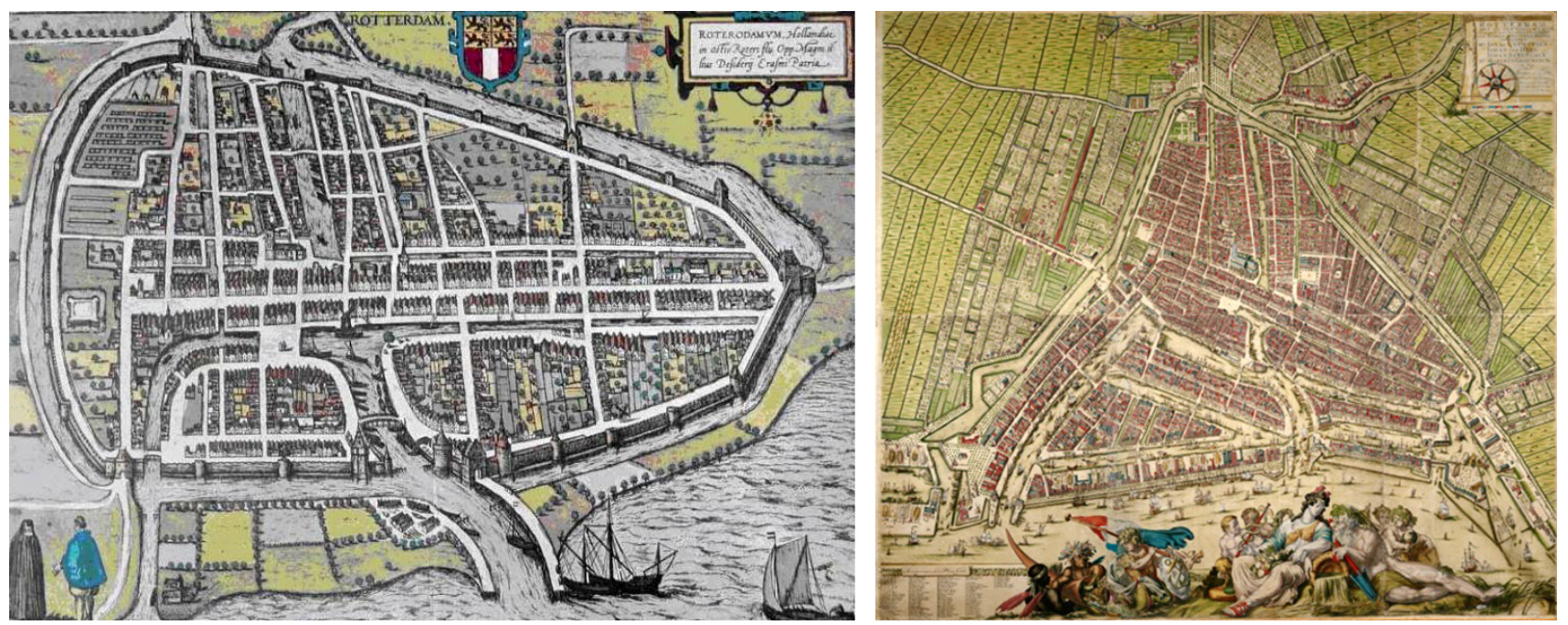

Figure 2. Rotterdam in 1588 and 1694. (a) Map of Rotterdam by F. Hogenberg, 1588 (left); (b) map of Rotterdam by Johannes de Vou en Romeijn de Hooghe, 1694 (right). Sources: Rotterdam City Archives (2009) and Hoogheemraadschap van Schieland en de Krimpenerwaard (2017). 
urban spaces. Water access was a privilege largely reserved for trade. Rapid growth of trade, the emergence of petroleum as a fuel, and urbanization required port and city expansion. Private and public companies created new land in the estuary and made new docklands. In Hamburg, the general plan for the expansion of the port was adopted in 1860 . The first harbor basin, the Sandtorhafen, was built between 1863 and 1866 on the Großer Grasbrook in front of the former sand gate of the destroyed city wall (see Figure 4). Land use plans for Rotterdam show that as the city of Rotterdam expanded along the south bank of the river Maas, designated port areas were drawn up, such as for the Rijnhaven (1887-1895) and Maashaven (1898-1905), for port purposes - that is, as harbors for the transhipment of bulk goods (see Figure 5). The land use register at the beginning of the 19th century for Koper shows residential buildings, buildings of special importance, green areas, and streets with squares (Figure 6). The harbors on the edge of the island were only defined by a line and no land use category was indicated for this land. During the period when the city and the port merged, Koper had already lost its importance due to the reduced accessibility of the port (Figure $3 \mathrm{~b}$ ) and the lost power of its protector, Venice. It was overtaken by the neighboring port of Trieste, which by the 1910s had become the fifth-largest port in Europe and the eighth largest in the world.

\section{Contemporary Land Use in the EU and National Databases}

In recent decades, Hamburg, Rotterdam, and Koper have started to expand their port areas further toward the sea and have begun to redevelop old port areas. All three ports have transit functions, but they differ in ranking, total port size, and in the ratio of city and port areas. The port of Rotterdam is the largest port in Europe, followed by Hamburg as the third largest on the continent. Koper is at least equal if not leading among the North Adriatic Ports Association ports. Although the total port area of Koper (760 ha) is much smaller than that of Hamburg and Rotterdam, the share of the urban area used for port activities is much larger; the port area occupies half of the built-up area of the settlement (Figure 7c). In Rotterdam, port areas also occupy a relatively large share of the urban land area; here, more than 30 percent (Merk, 2013, p. 39) of the urban land area is used for port activities (total area of $12,713 \mathrm{ha}$ ), although a large part of the port is located outside the city and the built-up area (Figure 7b). The port of Hamburg, which is located near the center of the city, but on the other side of the river, occupies just over 5 percent (total area of 4,331 ha) of the urban land area (Figure 7a; Merk, 2013, p. 39).

\subsection{Existing Land Use Categories of Port Territories in the EU and National Databases}

Port areas are not classified in the INSPIRE existing land use databases (HILUCS, or The Hierarchical INSPIRE Land Use Classification System, provides an application schema for land use data that defines a range of keys, but is as open as possible with respect to specific - national, European, and global-classification systems), although some land use types, such as specific types of raw material industries, commercial services and logistics and storage services, can be used to determine land use in port areas (European Parliament \& Council of the EU, 2007). In the European land cover databases, port areas are better classified and port areas have their own classification (123 port area), further defined by type (12310 cargo port, 12320 passenger port, 12330 fishing port, 12340 naval port, 12350, 12360 local multi-purpose ports, and 12370 shipyards; Copernicus, 2018b).

In Germany, the Amtliches Topographisch-Kartographisches Informationssystem (ATKIS) also distinguishes port areas from their surroundings by categorizing the port as a 'Hafen,' but the industry in the port is not further defined (see Figure 8a). In the Netherlands, port areas (including chemicals, refineries, liquid and dry bulk, distribution, container storage, offshore activities, etc.)
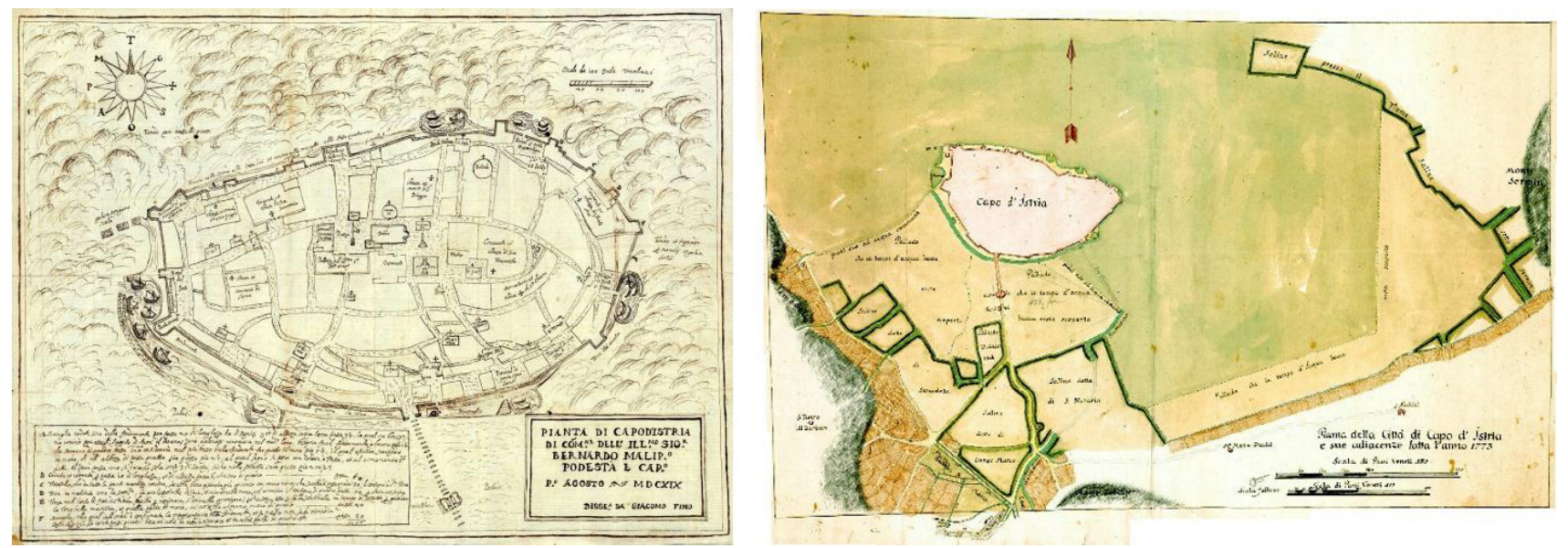

Figure 3. The island of Koper in 1619 and 1773. (a) Island of Koper in 1619 by Giordano Fino (left); (b) Island of Koper in 1773 by unknown author (right). Sources: Krmac (2009) and Archivio di Stato di Trieste (2021a). 

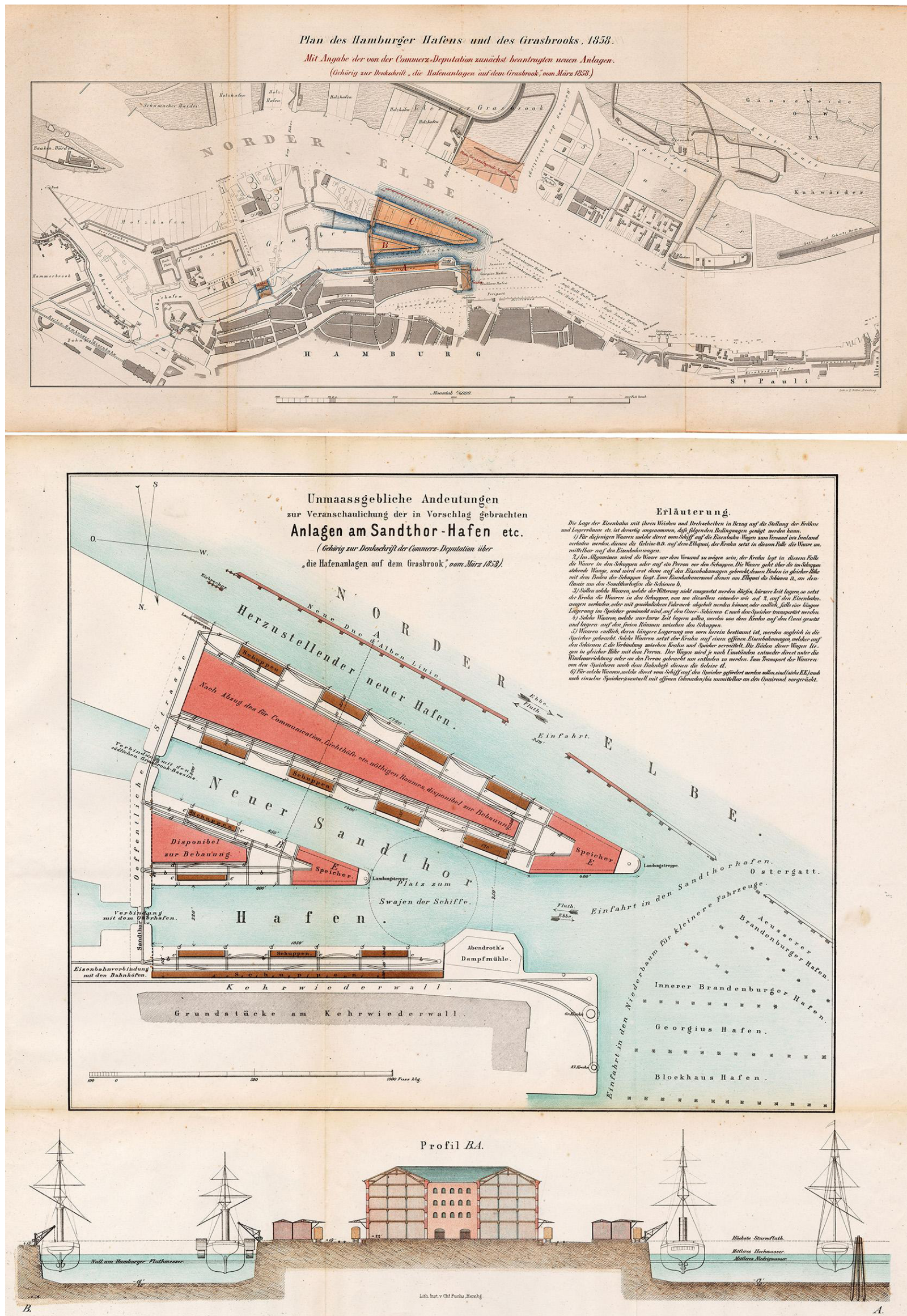

Figure 4. Plan of the port of Hamburg and the Grasbrook, with a proposal for used equipment at the Sandthor port. Source: Commerz-Deputation (1858). 


\section{COGITATIO}

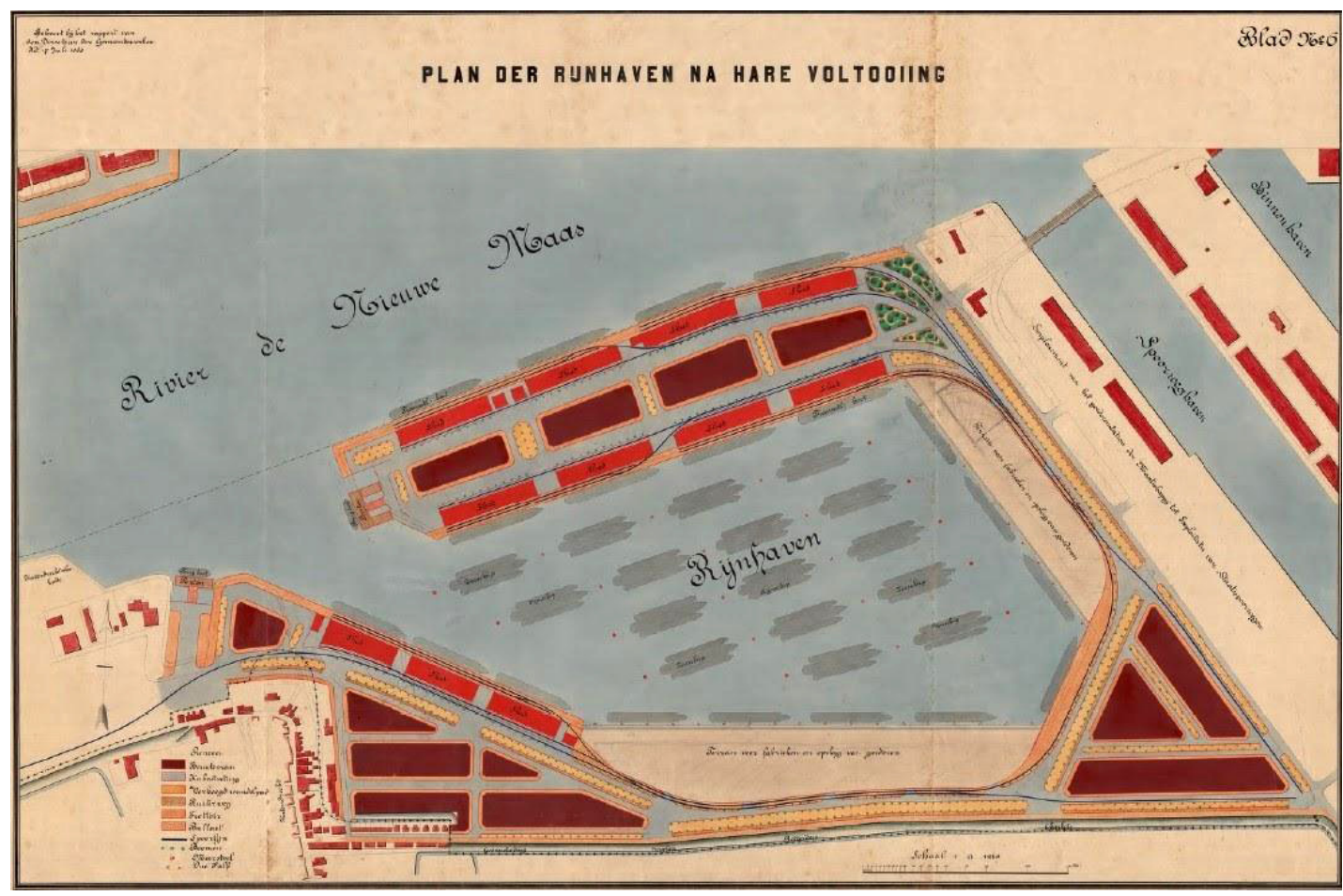

Figure 5. Expansion and zoning plan of the Rijnhaven by Gerrit de Jongh, director of the Rotterdam Municipal Works, 1888. This is one of the first plans for the south bank of Rotterdam, with land use exclusively for port activities. Source: de Jongh (1888).

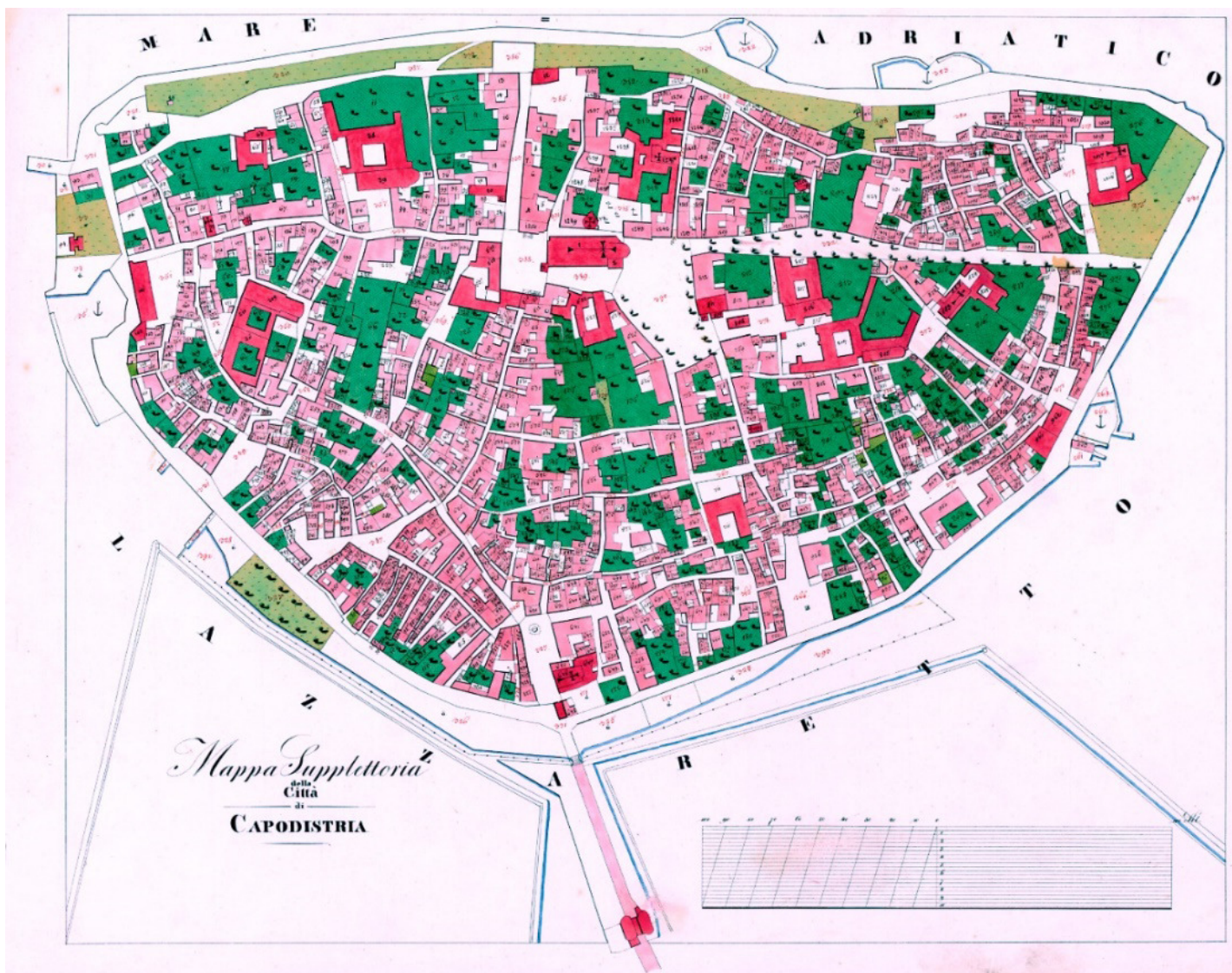

Figure 6. Map of Koper by The Franciscean or Stable cadastre from 1819. Source: Archivio di Stato di Trieste (2021b). 

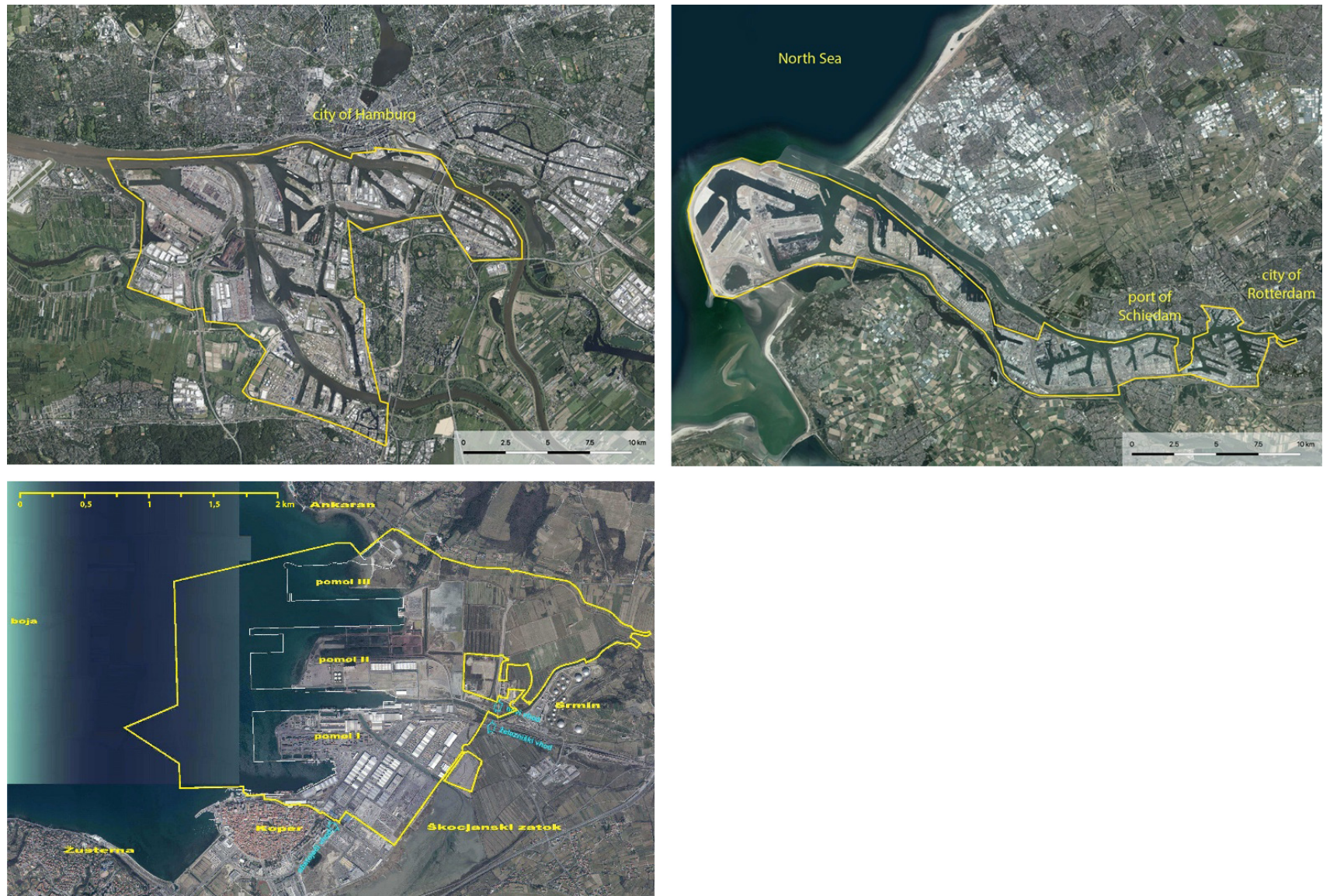

Figure 7. Sizes of the ports of Hamburg, Rotterdam, and Koper. (a) Size of the port of Hamburg in relation to the city and its surroundings. (top left); (b) size of the port of Rotterdam in relation to the city and its surroundings (top right); (c) the border of the national spatial plan for the port of Koper, 2011, which includes other land uses within the border area in the northern part (recreational areas, military zone, etc.) and in the south (bus station, etc.; bottom). Sources: ESRI Google Satellite and The Ministry of Environment and Spatial Planning of the Republic of Slovenia (2011).

are not defined separately in the Bestand Bodemgebruik (BBG) of the National Statistics Department and are categorized under 'commercial area,' as a subcategory of 'built-up area.' As a result, neither port is demarcated from surrounding areas and there is an overlap of land use between the city, the port, and the surrounding region (see Figures $8 \mathrm{a}$ and $8 \mathrm{~b}$ ). The surveying authorities in Slovenia only recently classified port area types among more detailed existing land use categories (Legal Order of the Republic of Slovenia, 2018), but this is not yet visible in the existing land use map and the port of Koper does not seem to have a clear demarcation of the port areas (Figure 8c), similar to the ports of Hamburg and Rotterdam.

\subsection{Planned Land Use Categories of Port Territories in the EU and National Databases}

In the current planning system, port designs begin based on existing land use, and when the design is complete, it defines the planned land use. INSPIRE has made recommendations for a classification for 'Planned Land Use' that includes supplementary regulation value based on types of conditions and constraints in spatial plans: the Hierarchical Supplementary Regulation Code List. This list has a class for port activities, defined as "harbor key functions associated with municipalities or regions on regional or state level planning" (INSPIRE Thematic Working Group Land Use, 2013, p. 168). This corresponds to the official zoning plan of the City of Hamburg. The port is classified as 'Hafen,' which creates a clear demarcation of the port area comparable to the existing land use data set ATKIS (see Figures 8a and 9). The category 'industry' in the ATKIS has disappeared in the planned land use data set, but the plan does indicate areas for supply systems and the recovery or disposal of sewage and solid waste.

The smaller-scaled zoning plan for the extension of the port of Rotterdam does not appear to provide more detailed information on land use. In the BBG, the existing land use in the port is classified as commercial area, which is consistent with the official planned land use in the municipality's land use plan for Maasvlakte II (see Figures $8 \mathrm{~b}$ and $10 \mathrm{~b}$ ). However, if we look at a design for the planned land use for Maasvlakte II, the land use is much more precise and is classified as chemical 

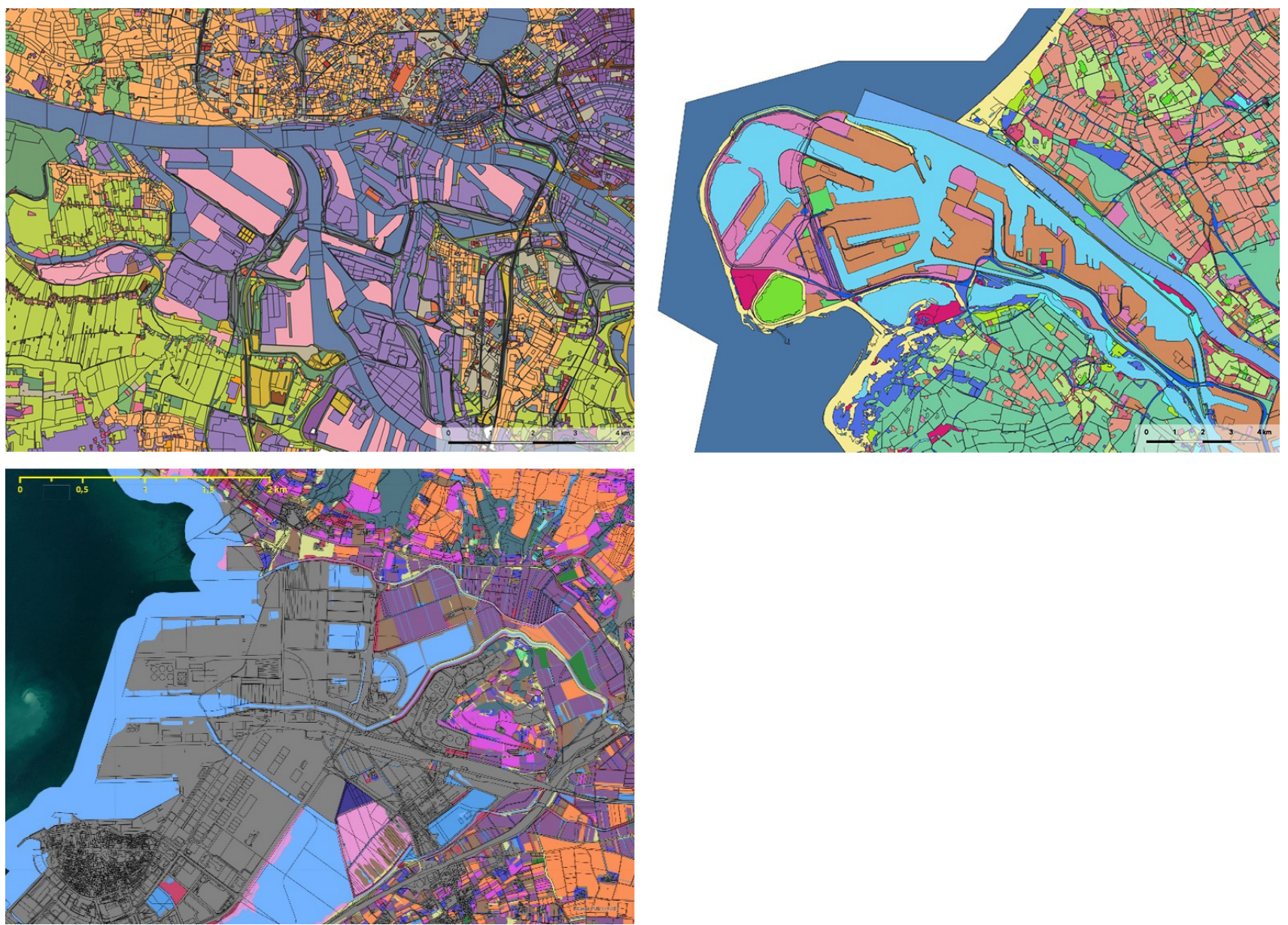

Figure 8. Fragments of the existing land use map of the ports of Hamburg, Rotterdam, and Koper. (a) Fragment of the existing land use map of the port area of Hamburg, based on the Landesbetrieb Geoinformation und Vermessung data set, which distinguishes between port area (pink) and industrial area (purple; top left); (b) fragment of the existing land use map of the port of Rotterdam and Maasvlakte II, based on the Dutch land use data set BBG 2015, in which the port area is defined as commercial (pink-orange-like), building site (light pink), and natural terrain (dark pink), as Maasvlakte II was still under construction in 2015 (top right); (c) existing land use and cadastre in the port area of Koper (the new categories in port areas are not yet applied; bottom). Sources: Landesbetrieb Geoinformation und Vermessung (2020), Publieke Dienstverlening Op de Kaart (2008), and The Ministry of Agriculture, Forestry and Food (2021).

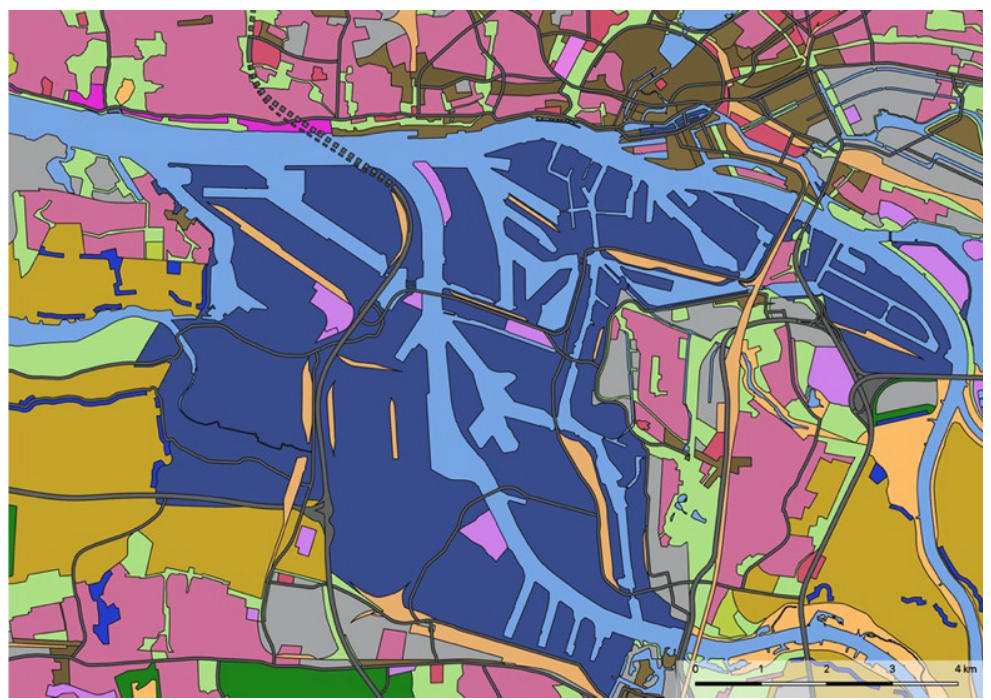

Figure 9. Official zoning plan/land use plan for the City of Hamburg of 2020. Similar to the land use data set ATKIS, the port is defined as 'Hafen' (blue), but not further specified. Source: Stadtentwicklung und Wohnen Hamburg (2020). 

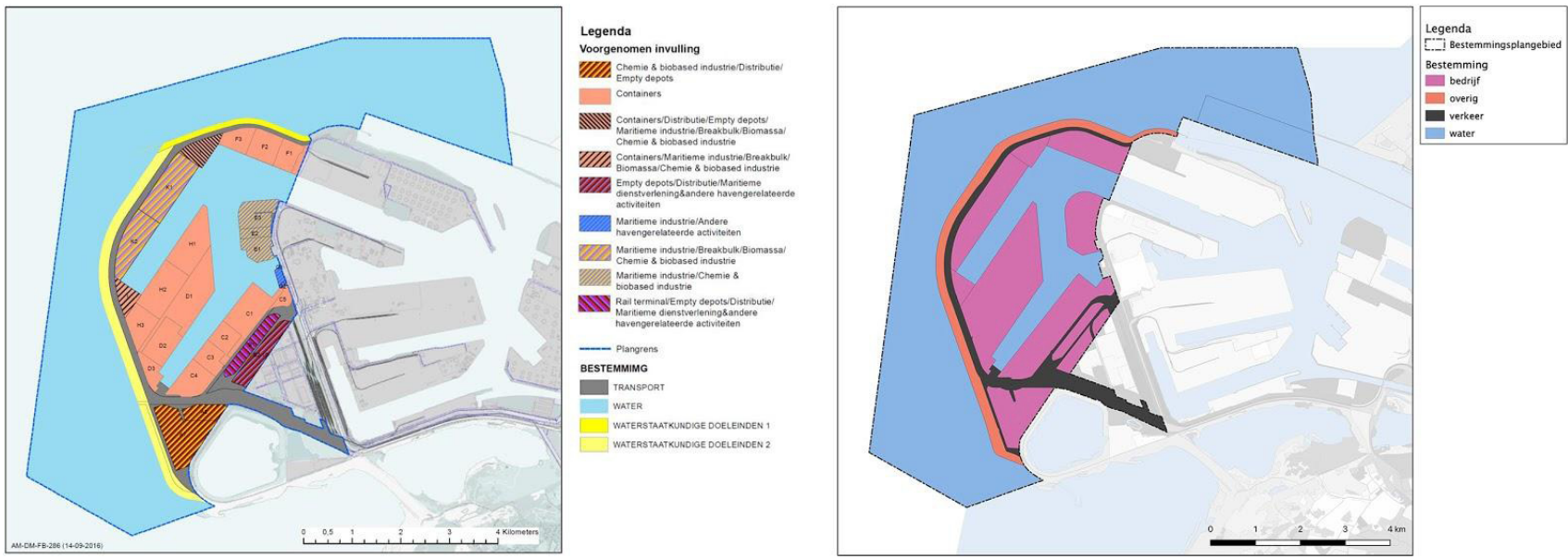

Figure 10. Zoning plans for Maasvlakte II. (a) A design for an 'intended land use' of Maasvlakte II established by Arcadis commissioned by the Port authority of Rotterdam, 2017 (left); (b) Official zoning plan/land use plan of the municipality of Rotterdam for Maasvlakte II, 2018 (right). Source: Arcadis (2017).

and bio-based industries, containers, distribution, empty depots, maritime industries, biomass, general cargo, maritime services, and other port-related activities (see Figure 10a).

The master plan for the port of Koper is a set of long-range planning documents that provide guidelines for future port growth and development (see Figure 11c) and gives an idea of future port development until 2030. There, the port structures are divided into car terminal, container terminal, fruit terminal, bulk terminal, European energy terminal, liquid cargo terminal, grain terminal, general cargo terminal, and transport networks with main and secondary roads and railway tracks (Figure 11a). If we compare this plan with existing land use, the detailed land use and the outer contours of the new design on the water side are lost (Figure 11b). This could only be a technical problem (perhaps the data set has not been renewed), as the contours of the old plan for the port of Koper are drawn in on the seaward side, and in contrast, on the landward side, the demarcation according to the new design plan is clearly visible. Another inaccuracy is the division of land within the fence around the port: it still represents the old agricultural land use patterns and not the existing or planned land use.

\section{Porosity of Port Areas in the Three Selected Port Cities}

Porosity of land use in the port areas of Hamburg, Rotterdam, and Koper can be observed in the current state and in the future planning proposals such as zoning plans and master plans. Looking at the various land use data, the port areas of Hamburg, Rotterdam, and Koper appear less delineated than they actually are; many port areas are fenced off and inaccessible. There seems to be a complete void of land use categories in the ports, while on satellite images such as Google Earth, numer- ous types of port functions are visible; in addition to the various industrial complexes devoted to chemical companies, oil refineries and the storage of containers, wet and dry bulk, there are a variety of office buildings, educational institutions, information centers, catering facilities, and so forth. Such a lack of demarcation can be also seen as a kind of porosity.

For interventions into the port areas (as a consequence of port expansions) or redevelopment of old port areas (as a consequence of the port leaving part of the city) mixed uses prevail. Hamburg is expanding the port in the direction of the Southern Elbe (Süderelbe) and is working on the Hafencity (including Grasbrook) redevelopment project. The port of Rotterdam is expanding with newly created areas in the North Sea (Maasvlakte I and II) and historic port areas near the old city centerMaritime District on the north bank (waterstad) and Kop van Zuid and Katendrecht on the south bank of the Maas (Rijnhaven)-are being reclaimed by the city and transformed into urban areas. The port of Koper withdrew from the old city center and made plans to expand the port territory into agricultural land in the adjacent hinterland. The port is currently closed off from the rest of the city. In order to link the separate parts of the city and the landscape, the new port design plan introduced distinctive landscape features (e.g., agricultural terraces, agricultural land uses on the roofs of the garages), hiding port boundaries and incorporating other land uses within the port area. Such porosity is not visible on the master plan layout, nor on the planned land use plan (as land use is only a two-dimensional tool), but only in the photomontage of the future development of the port on the orthophoto image (Figure 11c).

This comparison of land use of the master plans and legal planning documents in port areas of the three selected port cities confirms that port land uses are not classified precisely enough (e.g., defining specific land use keys) in land use data sets to permit easy recognition 

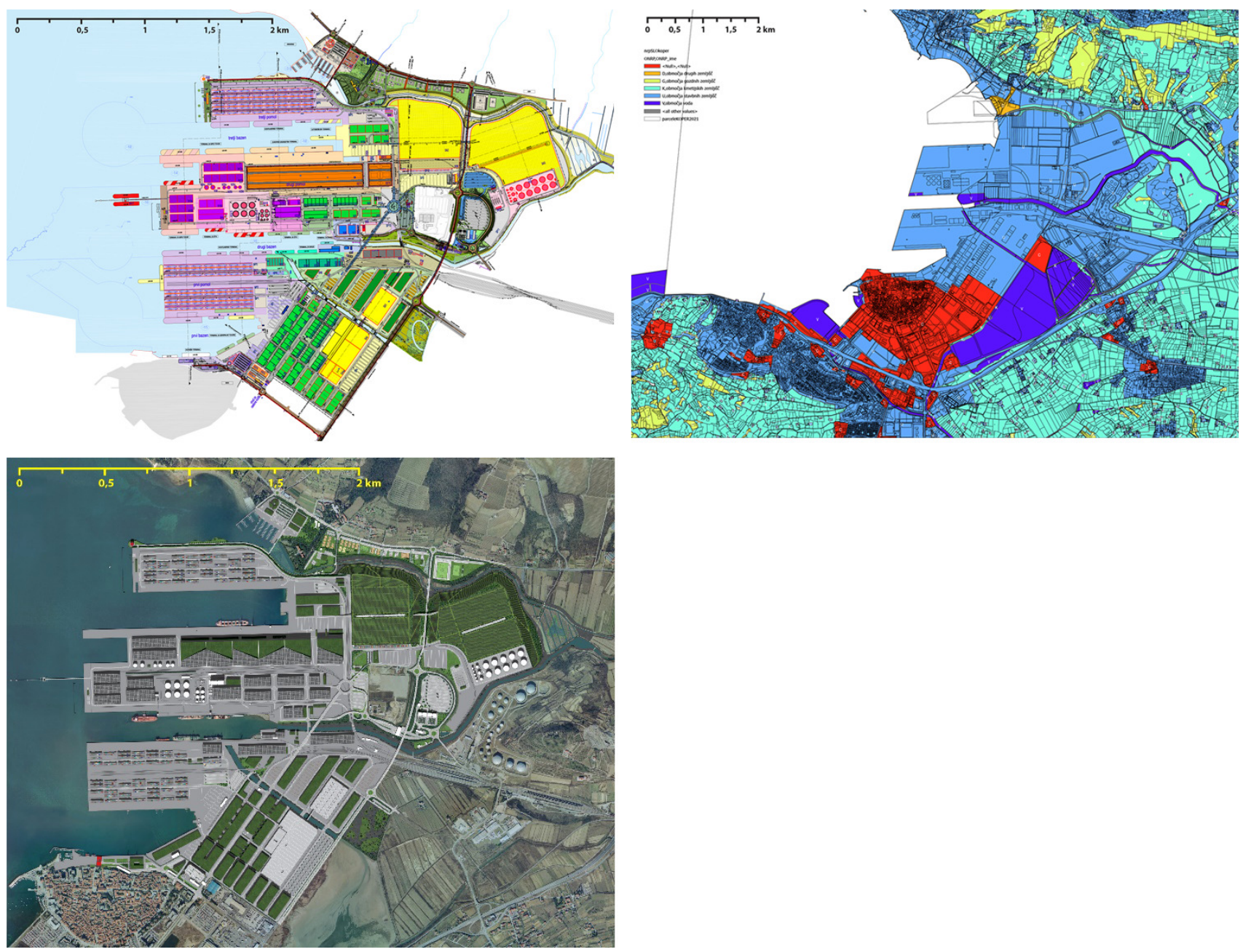

Figure 11. The port of Koper. (a) Professional guidelines for the master plan of the port of Koper with expected future development until 2030 (top left); (b) generalized planned land use database of the same area (top right); (c) orthophoto image of the future development (bottom). Sources: Ažman Momirski and Venturi (2010) and The Ministry of Environment and Spatial Planning of the Republic of Slovenia (2021).

of port activities in detail. The choice of land use keys for port areas is not determined by the size and functions of the ports, different social systems and different parts of a continent or sea. It is defined by the activities within the fence of the ports and is general for all ports. Although the land use categories do exist, as can be viewed in master plans for Maasvlakte II as well as in the expansion plan for the port of Koper, they appear in simplified versions in existing and planned land use data sets. European land use and land cover data sets contain some categorization of land use in port areas.

\section{Conclusions}

Design for master plans defines land use in detail. But when this detailed information is converted to another database-in our example, land use records-it is lost, and huge port areas appear empty in land use representation, which is misleading. Introducing more detailed land use categories and a shared European land use categorization in port areas would bring a clear understand- ing of the general pattern of waterfront land use and of the similarities and differences in waterfront land use patterns. In order to have a better idea of the visible and invisible boundaries between port and city, a more detailed delineation and transparent publication of functional areas within ports is needed. Detailed land use keys can help integrate the current multiplicity of planning documents and databases. Waterfront land can be viewed as a natural resource to be managed wisely with the goal of improving the quality and efficiency of its use (Forward, 1969). Comparative studies of a larger number of ports would be possible, if data concerning port use were available. Precise data would also help port authorities redefine the port's relationship with border areas. When port land requirements extend beyond the boundaries of the port, land use planning and control by legislation alone can cause serious problems, including inflexibility, delay, and divided responsibility. The boundaries between city and port, and between the port and rural areas, have become increasingly important issues in advancing contemporary urban design port concepts. 
Such proposals at the same time strengthen the professional importance of spatial planning as well as its innovative nature (Ažman Momirski, 2010). Land use concepts must adapt, and they need to be more detailed, with more specific categories of existing and planned land use.

\section{Acknowledgments}

The authors are grateful for the excellent feedback provided by the anonymous reviewers and would like to thank Tomaž Berčič for preparing the land use maps for the port of Koper.

\section{Conflict of Interests}

The authors declare no conflict of interests.

\section{References}

Albrechts, L. (2006). Shifts in strategic spatial planning? Some evidence from Europe and Australia. Environment and Planning A, 38(6), 1149-1170.

Antunes, C. (2010). Early modern ports, 1500-1750. European History Online. http://www.ieg-ego.eu/ antunesc-2010-en

Arcadis. (2017). MER Bestemmingsplan Maasvlakte 2: Samenvatting [MER zoning plan Maasvlakte 2: Summary]. https://commissiemer.nl/projectdocumenten /00002333.pdf

Archivio di Stato di Trieste. (2021a). Pianta della Città di Capo d'Istria e sue adiacenze fatta l'anno 1773 [Map of the town of Capo d'Istria and its surroundings made in the year 1773] [Map]. http://www.catasti. archiviodistatotrieste.it/Divenire/document.htm? idUa $=10653495$ \&idDoc $=10666429$ \& first $=0$ \&last $=0$

Archivio di Stato di Trieste. (2021b). Mappa catastale del Comune di Capodistria foglio I, sezione I [Cadastral map of the Municipality of Koper sheet I, section I] [Map]. http://ariannaweb.archiviodistatotrieste.it/ AriannaWeb/main.htm?eads $=* \# 4680 \_$archivio

Ažman Momirski, L. (2010). Port of Koper: New models of port-city relationship. Portus, 10(20), 12-17.

Ažman Momirski, L. (2017). Integration of land and sea in a port area: A case study of the Port of Koper. IOP Conference Series, Materials Science and Engineering, 245(6), 1-8. https://doi.org/10.1088/1757899X/245/6/062044

Ažman Momirski, L., \& Venturi, M. (2010). Professional guidelines for the master plan of the port of Koper. Lučka Ažman Momirski. http://lam.site44.com/17_ koper-eng.html

Bičík, I., Kupková, L., Jeleček, L., Kabrda, J., Štych, P., Janoušek, Z., \& Winklerová, J. (2015). Land use changes in the Czech Republic 1845-2010: Socioeconomic driving forces. Springer.

Boys, W. (1792). Collections for an history of Sandwich in Kent: With notices of the other cinque ports and mem- bers, and of Richborough. Simmons, Kirkby \& Jones. Commerz-Deputation. (1858). Die Hafenanlagen auf dem Grasbrook [The port facilities on the Grasbrook]. Christian Terstegge. https://www.christianterstegge.de/hamburg/karten_hafen/index.html

Copernicus. (2016). CORINE Land Cover. Version 18.5 [Data set]. https://land.copernicus.eu/local/coastalzones/coastal-zones-2018

Copernicus. (2018a). Urban atlas [Data set]. https://land. copernicus.eu/local/urban-atlas

Copernicus. (2018b). Coastal zones urban atlas [Data set]. https://land.copernicus.eu/local/coastal-zones/ coastal-zones-2018

de Jongh, G. (1888). Plan der rijnhaven na hare voltooiing [Plan of the Rijnhaven after its completion]. Wikipedia. https://nl.m.wikipedia.org/wiki/Bestand: Plan_Rijnhaven_Rotterdam_1888.jpg

De Langen, P. (2005). Trends and opportunities for the long-term development of Rotterdam's port complex. Coastal Management, 33(2), 215-224. https://doi. org/10.1080/08920750590919691

Desfor, G., \& Laidley, J. (2011). Changing urban waterfronts: A fixity and flow perspective. PORTUSplus, 1, $1-7$.

Dobner, K. (1973). Information requirements in an urban cadastre system: Report to Pan American Institute of Geography and History. Organization of American States, Pan American Institute of Geography and History.

European Parliament, \& Council of the European Union. (2007). Directive 2007/2/EC of the European parliament and of the council of 14 March 2007 establishing an infrastructure for spatial information in the European community. https://eur-lex.europa.eu/eli/ $\operatorname{dir} / 2007 / 2 / o j$

Eurostat. (2021). Land use and coverage area frame survey [Data set]. https://ec.europa.eu/eurostat/web/ lucas

Flämig, H. (2013). Infrastructure and environmental policy on regulating and vehicle emissions: From topdown policy directives to the local level. In P. Hall \& M. Hesse (Eds.), Cities, regions and flows (209-225). Routledge.

Forward, N. C. (1968). Waterfront land use in metropolitan Vancouver, British Columbia. Geography Paper, 41, 1-54.

Forward, N. C. (1969). A comparison of waterfront land use in four Canadian ports: St. John's, Saint John, Halifax and Victoria. Economic Geography, 45, 155-159.

Forward, N. C. (1970). Waterfront land use in the six Australian state capitals. Annals of the Association of American Geographers, 60(3), 517-532.

Hall, P. V. (2007, May 2-4). Global logistics and local dilemmas [Paper presentation]. International Conference on Gateways and Corridors, Vancouver, Canada. Hall, P., \& Hesse, M. (Eds.). (2013). Cities, regions and flows. Routledge.

Hein, C. (Ed.). (2011). Port cities: Dynamic landscape and 
global networks. Routledge.

Hein, C. (2018a). Oil spaces: The global petroleumscape in the Rotterdam/The Hague area. Journal of Urban History, 44(5), 887-929.

Hein, C. (2018b). "Old refineries rarely die": Port city refineries as key nodes in the global petroleumscape. Canadian Journal of History/Annales canadiennes d'histoire, 55(3), 457-486.

Hein, C., \& Van de Laar, P. (2020). The separation of ports from cities: The case of Rotterdam. In A. Carpenter \& R. Lorenzo (Eds.), European port cities in transition (pp. 265-286). Springer.

Hein, C., \& van Mil, Y. (2019). Towards a comparative spatial analysis for port city regions based on historical geo-spatial mapping. PortusPlus, 8, 1-18.

Hoffmann, G., \& Frank, J. W. (2009). Hamburg in historischen Karten: 1528 bis 1920 [Hamburg in historical maps: 1528 to 1920]. Sutton Verlag Gmbh.

Hoogheemraadschap van Schieland en de Krimpenerwaard. (2017). Rotterdam met al syn gebouwen, net op haer maet geteekent en gesneden, 1694 [Rotterdam with all its buildings, 1694] [Map]. https:// www.archieven. $\mathrm{nl} / \mathrm{nl} /$ zoeken ?mivast $=0$ \& mizig $=200 \&$ miadt $=150 \&$ miaet $=14 \&$ micode $=199 \& \operatorname{minr}=830672$ \&miview $=$ ldt

Hoyle, B. S. (1989). The port-city interface: Trends, problems and examples. Geoforum, 20(4), 429-435.

INSPIRE Thematic Working Group Land Use. (2013). D2.8.III.4 INSPIRE data specification on land useTechnical guidelines. European Commission Joint Research Centre.

Jansen, L. J. M., Badea, A., Milenov, P., Moise, C., Vassilev, V., Milenova, L., \& Devos, W. (2014). The use of the land-cover classification system in Eastern European countries: Experiences, lessons learnt and the way forward. In I. Manakos \& M. Braun (Eds.), Land use and land cover mapping in Europe (Vol. 18; pp. 297-325). Springer.

Jarvis, R. (1959). The appointment of ports. The Economic History Review, 11(3), 455-466. https://doi. org/10.2307/2591466

Kadaster. (2021). Basisregistratie Kadaster [Key register land registry] [Data set]. https://www.kadaster.nl/ zakelijk/registraties/basisregistraties/brk

Kain, R. J. P., \& Baigent, E. (1992). The cadastral map in the service of the state: A history of property mapping. University of Chicago Press.

Kipnis, J., \& Maymind, A. (2013). A question of qualities: essays in architecture. MIT Press.

Kliment, M., Kočica, J., \& Kliment, T. (2014). Land use dataset collection and publication based on LUCAS and HILUCS. Acta Horticulturae et Regiotecturae, 17(2), 52-59.

Kostrowicki, J. (1983). Land use systems and their impact on environment: An attempt at a classification. Advances in Space Research, 2(8), 209-215.

Krmac, D. (Ed.). (2009). Giacomo Fino: Pianta di Capod'Istria [Giacomo Fino: Map of Koper]. Società umanistica Histria / Humanistično društvo Histria / Humanističko društvo Histria.

Landesbetrieb Geoinformation und Vermessung. (2020). ATKIS Digitales Basis Landschaftsmodell Hamburg 2020 [digital basic landscape model Hamburg 2020] [Data set]. https://suche.transparenz.hamburg.de/ dataset/atkis-digitales-basis-landschaftsmodellhamburg24?forceWeb=true

Lee, S. W., \& Ducruet, C. S. (2009). Spatial glocalization in Asia-Pacific hub port cities: A comparison of Hong Kong and Singapore. Urban Geography, 30(2), 162-184.

Lee, S. W., Song, D.-W., \& Ducruet, C. S. (2008). A tale of Asia's world ports: The spatial evolution in global hub port cities. Geoforum, 39(1), 372-385.

Legal Order of the Republic of Slovenia. (2018). Uredba o dejanskih rabah zemljišč [Current land use ordinance]. http://www.pisrs.si/Pis.web/pregled Predpisa?id=URED7737

Loyen, R., Buyst, E., \& Devos, G. (Eds.). (2003). Struggling for leadership: Antwerp-Rotterdam port competition between 1870-2000. Physica-Verlag.

Merk, O. (2013). The competitiveness of global portcities: Synthesis report (Working Paper No. 2013/3). OECD.

Meyer, H. (1999). City and port: Urban planning as a cultural venture in London, Barcelona, New York, and Rotterdam: Changing relations between public urban space and large-scale infrastructure. International Books.

Middelton, N. (2005). Early medieval port customs, tolls and controls on foreign trade. Early Medieval Europe, 13(4), 313-358.

Minca, C. (1995). Urban waterfront evolution: The case of Trieste. Geography, 80(3), 225-234.

Moretti, B. (2019). Governance patterns on the urbanport threshold: The emergence of the city of the cluster. PortusPlus, 8, 1-17.

National Research Council. (1980). Need for a multipurpose cadastre. The National Academies Press. https://doi.org/10.17226/10989

Publieke Dienstverlening Op de Kaart. (2008). CBS Bestand Bodemgebruik 2008 [CBS land use data set 2008] [Data set]. https://www.pdok.nl/ downloads/-/article/cbs-bestand-bodemgebruik

Richeson, A. W. (1966). English land measuring to 1800. MIT Press.

Braun, G., \& Hogenberg, F. (1588). ROTERODAMUM, Hollandiae [Historical map]. Wikipedia. https://nl.m. wikipedia.org/wiki/Bestand:Map_of_Rotterdam_ 1588.jpg

Schubert, D. (2011). Seaport cities: Phases of spatial restructuring and types and dimensions of redevelopment. In C. Hein (Ed.), Port cities: Dynamic landscape and global networks (pp. 54-69). Routledge.

Stadtentwicklung und Wohnen Hamburg. (2020). Flächennutzungsplan der Freien und Hansestadt Hamburg 2020 [Land use plan of the Free and 
Hanseatic City of Hamburg 2020] [Data set]. https:// suche.transparenz.hamburg.de/dataset/ flachennutzungsplan-hamburg26?forceWeb=true

Takel, R. E. (1983). Planning land use in port areas: Getting the most out of port infrastructure. United Nations. https://unctad.org/system/files/officialdocument/ship4942_en.pdf

The Ministry of Agriculture, Forestry and Food. (2021). $R A B A$ [Data set]. https://rkg.gov.si/vstop

The Ministry of Environment and Spatial Planning of the Republic of Slovenia. (2011). National spatial plan for the port of Koper.

The Ministry of Environment and Spatial Planning of the Republic of Slovenia. (2021). Spatial information system [Data set]. https://dokumenti-pis.mop. gov.si/javno/veljavni

The Surveying and Mapping Authority of the Republic of Slovenia. (2020). Zemljiški kataster [Land cadastre]
[Data set]. https://www.e-prostor.gov.si/zbirkeprostorskih-podatkov/nepremicnine/zemljiskikataster

Unger, R. M. (1991). The better futures of architecture. In C. Davidson (Ed.), Anyone (pp. 28-36). Rizzoli.

Van den Berghe, K. (2016). Why are port cities geographically analysed? The ideal-typical concepts create an institutional lock-in. Ruimte \& Maatschappij, 7, 6-27.

Working Committee of the Surveying Authorities of the Laender of the Federal Republic of Germany. (2020). Real estate cadastre. http://www.adv-online.de/ icc/exteng/nav/504/50450570-6354-4c41-451e092672e13d63\&sel_uCon=5205da67-e55e-9fa6d787-9f08a07b51a6\&uTem=73d607d6-b048-65f180fa-29f08a07b51a.htm

Woudsma, C. (2013). Freight, land and local economic development. In P. V. Hall \& M. Hesse (Eds.), Cities, regions and flows (pp. 226-244). Routledge.

\section{About the Authors}

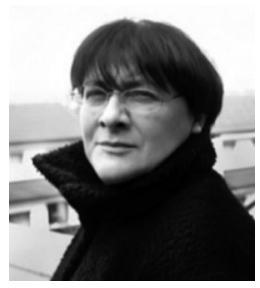

Lucija Ažman Momirski, PhD, is an Associate Professor of Urban Design at the University of Ljubljana. Her research interests lie in the past, present, and future spatial development of port city regions. She was the project leader of the professional guidelines for the overall spatial organisation of the Port of Koper, Slovenia, from 2007 to 2011, and published research papers, such as "The Resilience of the Port Cities of Trieste, Rijeka, and Koper" (2020) and "Shifts in Governance: Who Governs and What is Governed in the Port of Koper" (2020).

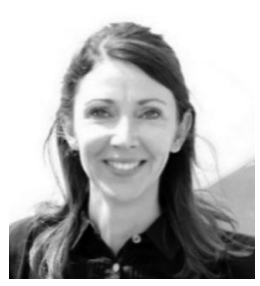

Yvonne van Mil is a Researcher in Spatial History and a Cartographer affiliated with Delft University of Technology. Her research topics include urban and spatial planning in the 19th and 20th century, focusing specifically on regional history and geo-spatial mapping. She was co-author of several books including Driven by Steel. From Hoogovens to Tata Steel 1918-2018 (2018) and contributed chapters to the Atlas of the Dutch Urban Landscape (2016).

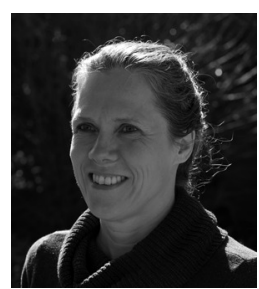

Carola Hein is Professor and Chair of History of Architecture and Urban Planning at Delft University of Technology. Her (co-)edited books and monographs include: Urbanisation of the Sea (2020), Adaptive Strategies for Water Heritage (2020), The Routledge Planning History Handbook (2018), Port Cities: Dynamic Landscapes and Global Networks (2011), Brussels: Perspectives on a European Capital (2007). She has also published numerous articles in peer-reviewed journals, books, and magazines. 